\title{
DNA bar-coding reveals source and patterns of Thaumastocoris peregrinus invasions in South Africa and South America
}

\author{
R. L. Nadel - B. Slippers - M. C. Scholes • \\ S. A. Lawson - A. E. Noack · C. F. Wilcken • \\ J. P. Bouvet · M. J. Wingfield
}

Received: 21 January 2009/Accepted: 2 July 2009

(C) Springer Science+Business Media B.V. 2009

\begin{abstract}
Thaumastocoris peregrinus is a recently introduced invertebrate pest of non-native Eucalyptus plantations in the Southern Hemisphere. It was first reported from South Africa in 2003 and in Argentina in 2005. Since then, populations have grown explosively and it has attained an almost ubiquitous
\end{abstract}

R. L. Nadel $(\bowtie) \cdot$ B. Slippers · M. J. Wingfield Department of Genetics, Forestry and Agricultural Biotechnology Institute (FABI), University of Pretoria, Pretoria 0002, South Africa

e-mail: Ryan.Nadel@fabi.up.ac.za

M. C. Scholes

School of Animal, Plant and Environmental Sciences, University of the Witwatersrand, Private Bag 3, Wits 2050, South Africa

\section{S. A. Lawson}

Department of Primary Industries and Fisheries, Forestry Building, Gate 3, 80 Meiers Rd., Indooroopilly, QLD 4068, Australia

\author{
A. E. Noack \\ Faculty of Agriculture, Food and Natural Resources, \\ University of Sydney, Sydney, NSW 2006, Australia \\ C. F. Wilcken \\ Department of Plant Production, Faculty of Agronomic \\ Sciences, Sao Paulo State University (UNESP), \\ Campus of Botucatu, Sao Paulo, SP, Brazil \\ J. P. Bouvet \\ INTA-Estación Experimental Agropecuaria de Concordia \\ CC34, Sección Entomología, Entre Ríos, Argentina
}

distribution over several regions in South Africa on 26 Eucalyptus species. Here we address three key questions regarding this invasion, namely whether only one species has been introduced, whether there were single or multiple introductions into South Africa and South America and what the source of the introduction might have been. To answer these questions, bar-coding using mitochondrial DNA (COI) sequence diversity was used to characterise the populations of this insect from Australia, Argentina, Brazil, South Africa and Uruguay. Analyses revealed three cryptic species in Australia, of which only T. peregrinus is represented in South Africa and South America. Thaumastocoris peregrinus populations contained eight haplotypes, with a pairwise nucleotide distance of $0.2-0.9 \%$ from seventeen locations in Australia. Three of these haplotypes are shared with populations in South America and South Africa, but the latter regions do not share haplotypes. These data, together with the current distribution of the haplotypes and the known direction of original spread in these regions, suggest that at least three distinct introductions of the insect occurred in South Africa and South America before 2005. The two most common haplotypes in Sydney, one of which was also found in Brisbane, are shared with the non-native regions. Sydney populations of $T$. peregrinus, which have regularly reached outbreak levels in recent years, might thus have served as source of these three distinct introductions into other regions of the Southern Hemisphere. 
Keywords COI diversity - Eucalyptus plantation forestry - Invasive insect pest . Thaumastocoridae . Hemiptera

\section{Introduction}

Commercial Eucalyptus forestry serves as a major source of fibre and wood production in many parts of the world (Turnbull 1999). By 2006, some 496,000 hectares of productive commercial forestry land in South Africa had been planted to non-native Eucalyptus (Forestry South Africa 2006). This resource is seriously threatened by alien invasive pests and pathogens (Wingfield et al. 2008; Wingfield et al. 2001). Accidental introductions and impacts of insect pests of trees appear to be increasing due to global trade and travel (Brockerhoff et al. 2006; Wingfield et al. 2008). Understanding the origin and patterns of these introductions is an important component of efforts to reduce them in the future.

The Eucalyptus pest Thaumastocoris peregrinus (Hemiptera: Thaumastocoridae), is a small (2-4.5 mm) insect belonging to the Thaumastocoridae, a family of true bugs first described by Kirkaldy (1908). The Thaumastocoridae includes three sub-families; namely the Thaicorinae from Thailand with one extant genus, the South American Xylastodorinae represented by two genera and six species and the Thaumastocorinae with four genera and 13 species (Cassis et al. 1999; Heiss and Popov 2002; Slater 1973). The latter group are phytophagous sap feeding insects from Australia, with only one genus and species occurring in Southern India (Drake and Slater 1957). The Thaumastocorinae have a wide host range including species of Acacia, Agonis, Banksia, Dryandra, Elaeocarpus, Eucalyptus, Melaleuca, Schizomeria and Xanthorrhoea, whereas the Xylastodorinae feed exclusively on Palmae (Carpintero and Dellapé 2006; Cassis et al. 1999; Hill 1988; Jacobs and Neser 2005; Kumar 1964; Slater 1973).

The genus Thaumastocoris included five species and was established in 1908 when Kirkaldy described Thaumastocoris australicus from specimens collected in Bundaberg, Queensland (Carpintero and Dellapé 2006; Kirkaldy 1908). Very little research had been conducted on Thaumastocoris prior to 2002 when
T. australicus became a major pest on planted Eucalyptus trees in Sydney (Noack 2002; Noack and Coviella 2006). This pest was first encountered in South Africa in 2003 and in 2005, it was found causing significant damage to plantation Eucalyptus spp. in the Gauteng, Mpumalanga and North West provinces (Jacobs and Neser 2005). Interestingly, around this time, a new species $T$. peregrinus (Carpintero and Dellapé 2006) was described from specimens collected on Eucalyptus spp. planted in the Buenos Aires province of northern Argentina. Carpintero and Dellapé (2006) speculated that T. peregrinus, classified only from specimens collected in Argentina, had been introduced into that country from Australia. The anterolateral tubercles on the anterior lobe of the pronotum in $T$. peregrinus are characteristic and these structures were also noted on the invasive Thaumastocoris sp. thought to represent T. australicus in South Africa (Carpintero and Dellapé 2006).

It is now believed that the initial reports of T. australicus outbreaks in Australia, Argentina and South Africa (Jacobs and Neser 2005; Noack and Coviella 2006) were incorrect and were in fact caused by the newly described species $T$. peregrinus (Carpintero and Dellapé 2006; A. Noack, unpublished data). The initial misidentification of $T$. peregrinus in South Africa, Australia and Argentina highlights the difficulty in differentiating between morphologically similar species of Thaumastocoris. This can have implications for understanding spread, collection of potential biological control organisms and other species-specific control strategies (Bickford et al. 2007). A potential solution to overcome such problems is to use DNA sequence data for the mitochondrial bar-coding gene, cytochrome $c$ oxidase subunit I (COI), for species identification (Hebert et al. 2003a, b, 2004). Such data also provide a measure of divergence amongst geographically distinct populations (Brown 2004).

Since December 2003, T. peregrinus has become one of South Africa's most significant Eucalyptus pests. It is currently distributed throughout South Africa and has moved northwards in Africa, reaching Zimbabwe in August 2007 and Malawi in June 2008. Similarly, $T$. peregrinus was reported as having become established in Argentina in April 2005 and it was recorded as established in Uruguay and Brazil in January and June 2008, respectively (Carpintero 
and Dellapé 2006; Noack and Coviella 2006; M. J. Wingfield and C. F. Wilcken, unpublished data). Typical symptoms of infestation include initial reddening of the canopy leaves on the north to north eastern side of a compartment (Fig. 1). Subsequently, the foliage changes to a reddish-yellow or yellowbrown colour. This is coupled with some leaf loss and the visible abundance of adults, nymphs and black egg capsules usually clustered in high numbers (Fig. 1). During severe infestations, loss of leaves leads to severe canopy thinning and this sometimes results in branch dieback (Fig. 1).

In this study, we use COI bar-coding sequences of T. peregrinus from native populations in Australia, and compare these with those of specimens from South African and South American Eucalyptus plantations. Using these data we considered whether only one species has been introduced into exotic Eucalyptus plantations of the Southern Hemisphere. We further attempted to determine the number and
Fig. 1 Symptoms of Thaumastocoris peregrinus infestations in several Eucalyptus plantations: a initial reddening of the canopy leaves.

b Progression of infestation severity coupled with foliage changing to a yellowish colour. c Feeding $T$. peregrinus adults.

d Clusters of black egg capsules on infested leaf surfaces.

e Severe infestation resulting in the loss of canopy leaves.

f Re-sprouting leaf shoots that are un-infested by $T$. peregrinus, with older leaves from a previous infestation
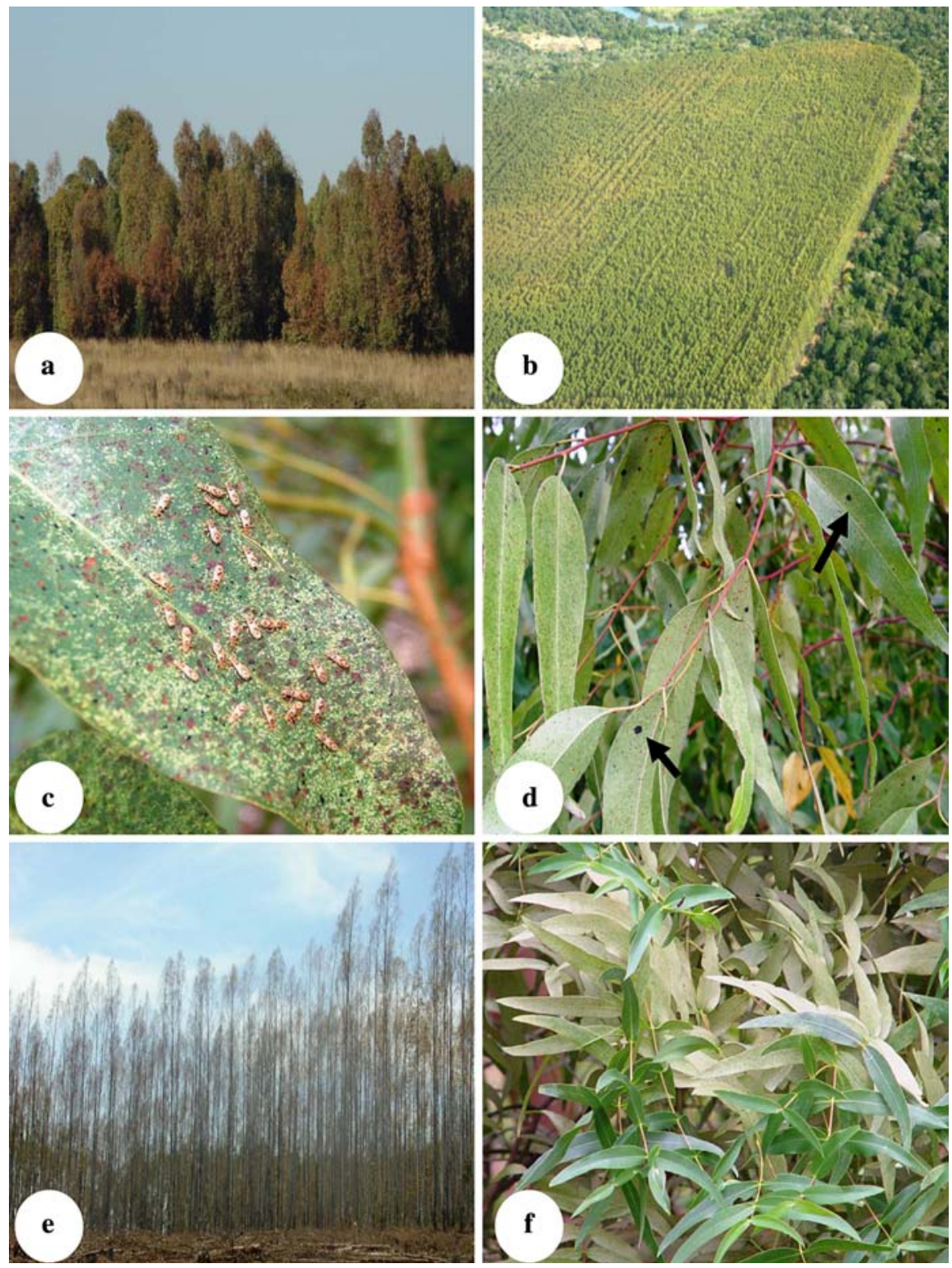
pattern of introductions into South Africa and South America and considered where the introductions might have originated.

\section{Materials and methods}

Host range, infestation and distribution

In South Africa, the host range and distribution of T. peregrinus was determined by field sampling and plantation surveillance over an 18-month period from February 2006 to July 2007. Assessments of infestations were carried out throughout South Africa, although they were strongly focussed on commercially grown Eucalyptus in plantations in the Limpopo, Mpumalanga and KwaZulu-Natal provinces. The surveys were undertaken in collaboration with forestry companies that form part of the Tree Protection Co-operative Programme (TPCP) (www.fabinet.up.ac.za/tpcp). Only 26 Eucalyptus species that were found to support several generations (life stages) of adults, nymphs and eggs of T. peregrinus were listed as being susceptible.

\section{Insect collection}

Thaumastocoris peregrinus individuals are gregarious with many adults and nymphs typically occurring on the same leaves. At least five adults and/or nymphs from several infested trees at an infested site were randomly collected to maximise the diversity sampled. Adults and nymphs were placed in labelled containers filled with $100 \%$ ethanol for subsequent DNA analysis.

In South Africa, thirty-one sites $(n=432$ individuals) were sampled three times between 2006 and 2008. In South America, two sites in Argentina $(n=14)$, three sites in Brazil $(n=15)$ and a single site in Uruguay $(n=10)$ were sampled between 2007 and 2008. In Australia, Thaumastocoris specimens were collected in and around three urban centres, namely those of Southeast Queensland, Perth and Sydney, in addition to surrounding rural areas. In May 2008 , one site $(n=7)$ was sampled in a rural area within the Brisbane region, in addition to the four sites $(n=20)$ in the Perth region. In Sydney, where $T$. peregrinus is a major pest on planted Eucalyptus, samples were collected from twelve sites
( $n=40)$ between 2001 and 2002, whereas five sites $(n=37)$ were sampled in May 2008.

DNA extraction and sequencing

Total genomic DNA was extracted from 657 adult T. peregrinus individuals using PrepMan ${ }^{\circledR}$ Ultra Sample Preparation Reagent (Applied Biosystems, California, USA). Mitochondrial COI gene PCR amplifications were initially undertaken using the primer pairs C1-J-2183 and TL2-N-3015 (Simon et al. 1994). From resulting sequences, a new set of primers was developed to increase efficiency using the software Primer 3 (Rozen and Skaletsky 1998) and Net Primer (PREMIER Biosoft International). A 547 base pair fragment of the mitochondrial COI gene was amplified using PCR with this newly developed primer pair Tp2390F (5'ACCCGAGCAT ACTTTACTTC) and Tp2937R (5'ATTGTGGCTCGTTTTGATA).

PCR reactions included $2 \mu \mathrm{l}$ of genomic DNA (50-100 ng/ $\mu \mathrm{l}$ ), 10× PCR buffer (Roche Diagnostics), $3 \mathrm{mM} \mathrm{MgCl} 2,1 \mathrm{mM}$ dNTP's, $0.4 \mu \mathrm{M}$ of each primer, $1 \mathrm{U}$ Taq polymerase with $12 \mu \mathrm{l}$ of Sabax water to bring the total volume of the reaction to $25 \mu \mathrm{l}$. The PCR cycling regime was as follows: initial denaturation at $95^{\circ} \mathrm{C}$ for $1 \mathrm{~min}$ followed by 30 cycles of $30 \mathrm{~s}$ at $95^{\circ} \mathrm{C}, 45 \mathrm{~s}$ at $48^{\circ} \mathrm{C}, 45 \mathrm{~s}$ at $72^{\circ} \mathrm{C}$, and a final elongation for $10 \mathrm{~min}$ at $72^{\circ} \mathrm{C}$. The PCR products were cleaned using the $3 \mathrm{M} \mathrm{NaOAc}(\mathrm{pH}$ 4.6) and Ethanol $\left(\mathrm{CH}_{3} \mathrm{CH}_{2} \mathrm{OH}\right)$ precipitation method prior to being visualized under UV on an Ethidium Bromide stained $2 \%$ agarose gel.

A total of 215 specimens from 22 locations in South Africa $(n=73)$, two locations in Argentina $(n=14)$, three locations in Brazil $(n=15)$, one location in Uruguay $(n=10)$ and 22 locations in Australia $(n=103)$ were sequenced. Sequencing reactions were performed in $10 \mu \mathrm{l}$ with $4 \mu \mathrm{l}$ of cleaned PCR product, $0.5 \mu \mathrm{M}$ of the same primers used for the PCR, $2 \mu 15 \times$ sequencing buffer and using the BigDye ${ }^{\circledR}$ Terminator v3.1 Cycle sequencing Kit (Applied Biosystems, Warrington, UK). PCR conditions were 25 cycles of $10 \mathrm{~s} 95^{\circ} \mathrm{C}$, $5 \mathrm{~s}$ at $48^{\circ} \mathrm{C}, 4 \mathrm{~min}$ at $60^{\circ} \mathrm{C}$. PCR products were purified by precipitation using $3 \mathrm{M} \mathrm{NaOAc}(\mathrm{pH} 4.6)$ and Ethanol $\left(\mathrm{CH}_{3} \mathrm{CH}_{2} \mathrm{OH}\right)$ followed by vacuum drying and sequencing using the ABI Prism ${ }^{\mathrm{TM}} 3100$ Genetic Analyzer (Applied Biosystems). Representative sequences were deposited in GenBank (FJ6237 60-FJ623773). 
mtDNA sequence analyses

Sequence alignments were done using Vector NTI 9.1 (Invitrogen Corporation, 2004). Phylogenetic and distance analyses were conducted using MEGA version 4 (Tamura et al. 2007). A pairwise distances matrix for haplotypes and species was produced using the Kimura 2-parameter model and a neighbour joining analysis was conducted for phylogenetic reconstruction. One thousand bootstrap replicates were done to assess the statistical support of the nodes in the phylogenetic tree.

The haplotype diversity was determined using DnaSP ver. 4.5 (Rozas et al. 2003). A parsimony haplotype network with $95 \%$ statistical support was obtained using TCS 1.21 (Clement et al. 2000) to determine the relationship among $T$. peregrinus haplotypes.

\section{RFLP analyses}

Sequences obtained from South African samples were analysed for variation in Restriction Enzyme (RE) sites. The two haplotypes found in South Africa differed at a restriction site for the enzyme AluI. PCR's using the same primers and conditions as described above were conducted on an additional 432 samples, which were then digested using the restriction enzyme $A l u I$. RFLP reactions were performed in $10 \mu \mathrm{l}$ reactions with $5 \mu \mathrm{l}$ of cleaned PCR product, $1 \mu \mathrm{l}$ of $10 \times$ Buffer Tango $^{\mathrm{TM}}$ (Fermentas Inc., Canada) and 10 units of $A l u \mathrm{I}$ restriction enzyme. The RFLP reaction was performed at $37^{\circ} \mathrm{C}$ for $1 \mathrm{~h}$, $20 \mathrm{~min}$ at $60^{\circ} \mathrm{C}$. The RFLP PCR product was visualized under UV on an ethidium bromide stained $2 \%$ agarose gel.

\section{Results}

Host range, infestation and distribution

Between 2005 and 2006 T. peregrinus spread throughout South Africa, infesting 26 Eucalyptus species (Fig. 2; Table 1). By mid 2006, it was found as far north as the Soutpansberg, Limpopo province, $\pm 400 \mathrm{~km}$ north of Pretoria (since August 2005) and as far south as Cape Town, Western Cape province, $\pm 1,450 \mathrm{~km}$ south of Pretoria (since May 2006) (Fig. 2). An infestation was first reported from the Southern coastal Zululand region, KwaZulu-Natal province in February $2006( \pm 600 \mathrm{~km}$ south east of
Fig. 2 Map of South Africa showing the confirmed infestations and date of first reported occurrences of

Thaumastocoris peregrinus. Sequence and RFLP data indicate the existence of two COI haplotypes. The provinces are labelled as follows Western Cape (WP), Eastern Cape (EC), Northern Cape (NC), Free State (FS), KwaZulu-Natal (KZN), Mpumalanga (MP), Limpopo (LP), Gauteng (GP) and North West provinces (NW)

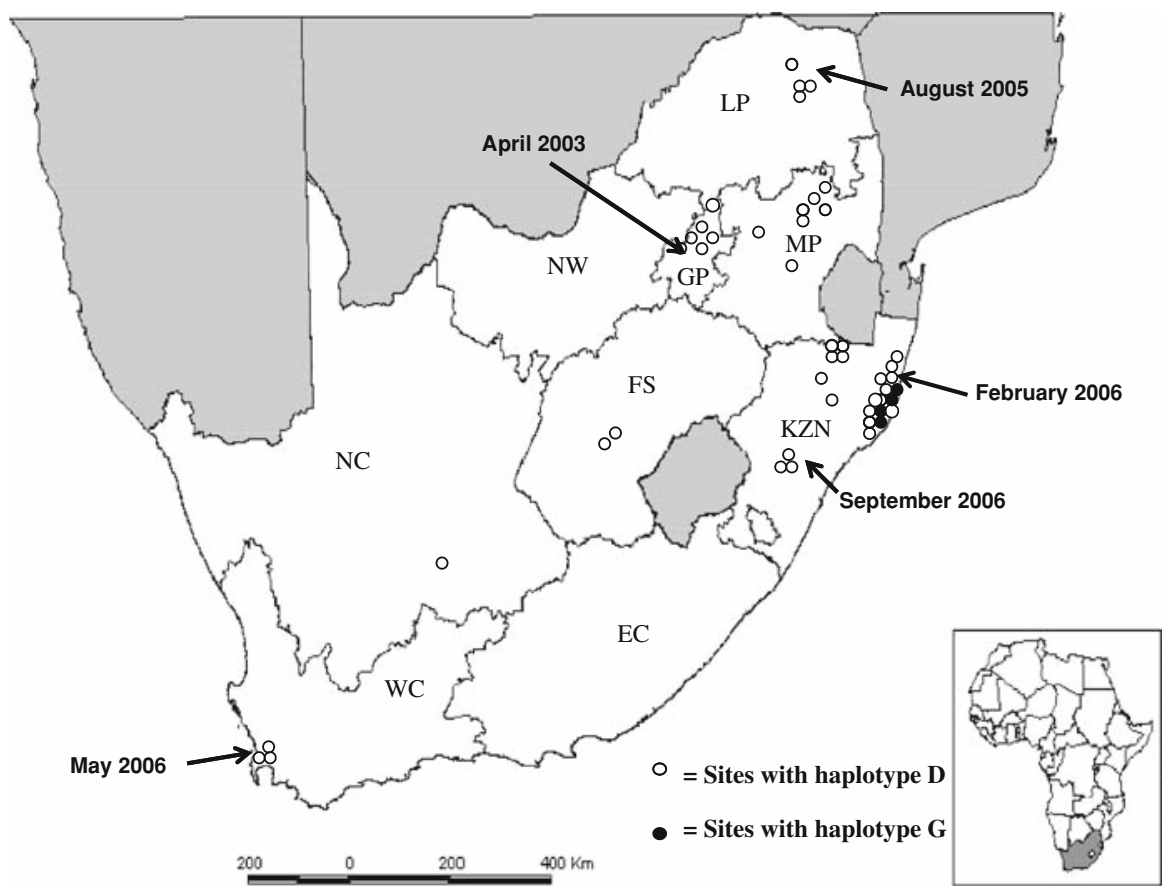


Table 1 Eucalyptus species infested by Thaumastocoris peregrinus in South Africa

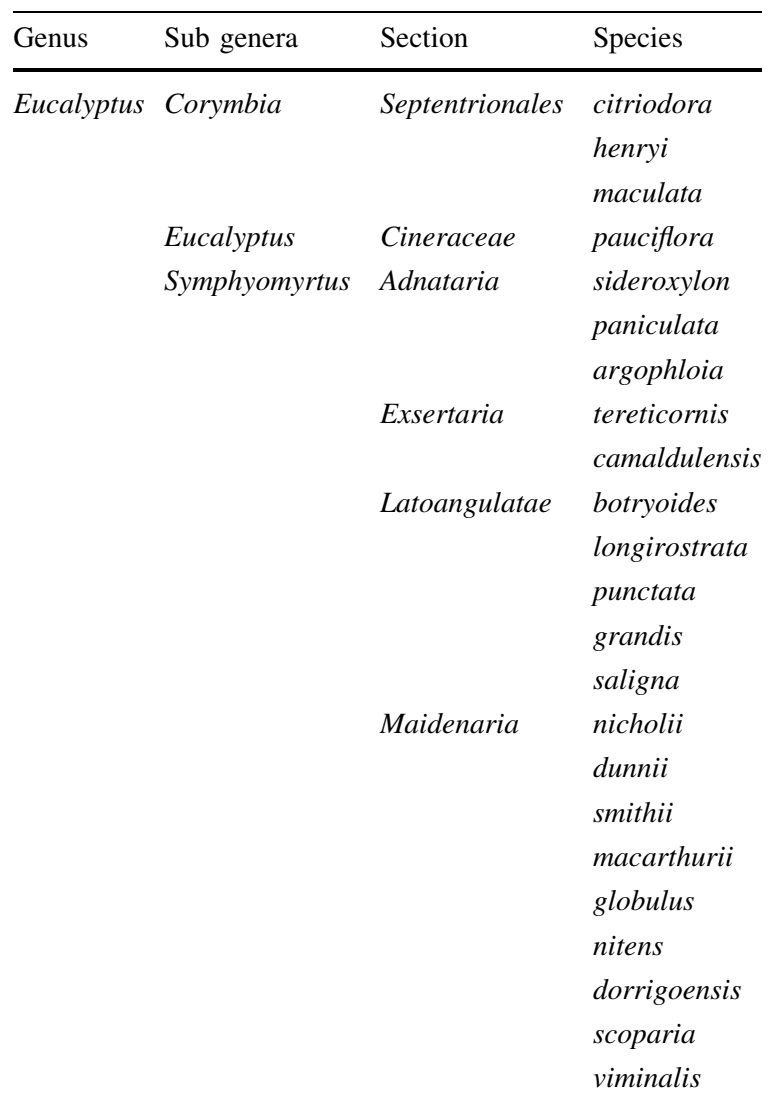

Eucalyptus hybrids

Eucalyptus grandis $\times$ camaldulensis

Eucalyptus grandis $\times$ nitens

Eucalyptus grandis $\times$ urophylla

Classification of Eucalyptus according to Brooker (2000)

Pretoria), with numerous other infestations reported further north along the coast in March 2006 (Fig. 2). More recent new infestations were reported from the interior Midlands region of KwaZulu-Natal in September 2006 (Fig. 2).

mtDNA analysis

Mitochondrial DNA (mtDNA) sequence analysis for Thaumastocoris specimens collected from 22 localities in Australia and 28 introduced localities in the South Africa and South America revealed three distinct clades differing by $6.7-8.7 \%$ (Fig. 3). One clade represents specimens collected exclusively from the Perth region of Western Australia, whereas a second clade contained specimens from the Sydney region. The remaining clade included specimens that were collected in Brisbane and Sydney (Australia), as well as Argentina, Brazil, South Africa and Uruguay. Specimens from this latter clade were confirmed by A. Noack (unpublished data) as T. peregrinus.

The $T$. peregrinus clade was further analysed for haplotype diversity for $186 \mathrm{~T}$. peregrinus individuals from 22 locations in South Africa, two locations in Argentina, three locations in Brazil, a single location in Uruguay and 17 locations in Australia. Pairwise genetic nucleotide distance calculations ranged between 0.2 and $0.9 \%$, characterised by nine polymorphic nucleotide sites. The haplotype diversity sampled from Australian T. peregrinus populations ranged between 0.52 and 0.75 with the highest diversity obtained from the Sydney (2001-2002) region and the lowest in Brisbane (2008) region (Table 2). Two haplotypes (B and F) were found to occur exclusively within Brisbane region in comparison to four haplotypes (A, C, E and $\mathrm{H}$ ) found to occur only within the Sydney region (Table 2). Haplotype D was shared among the two Australian regions whereas haplotype A was dominant and present only in the Sydney region (Table 2). Three haplotypes found amongst Australian samples (haplotype A, D and G) were also found in the non-native populations of $T$. peregrinus in Argentina, Brazil, Uruguay and South Africa. Haplotype A, was found to occur within South America whereas two haplotypes, D and G were found in South Africa (Table 2). The relationship among COI haplotypes as represented by the haplotype network (Fig. 4), indicate that the dominant haplotypes within the Australian population are those of haplotype A and D (Fig. 4).

\section{RFLP analyses}

Two mtDNA COI sequence haplotypes were identified amongst 432 specimens from thirty-one locations in South Africa using the restriction enzyme AluI, thus allowing for easy screening of the population for the two distinct haplotypes. A dominant haplotype $(n=399)$ was observed throughout South Africa across several climatic regions, including both summer and winter rainfall patterns (Fig. 2). A second haplotype ( $n=33$ ) was found only in three locations within the subtropical, summer rainfall area of the 
Fig. 3 A neighbour joining tree constructed using the Kimura 2-parameter distance model, between Thaumastocoris species and their associated haplotypes based on mtDNA COI data. Bootstrap values are presented at the nodes with the range of genetic divergences shown in brackets

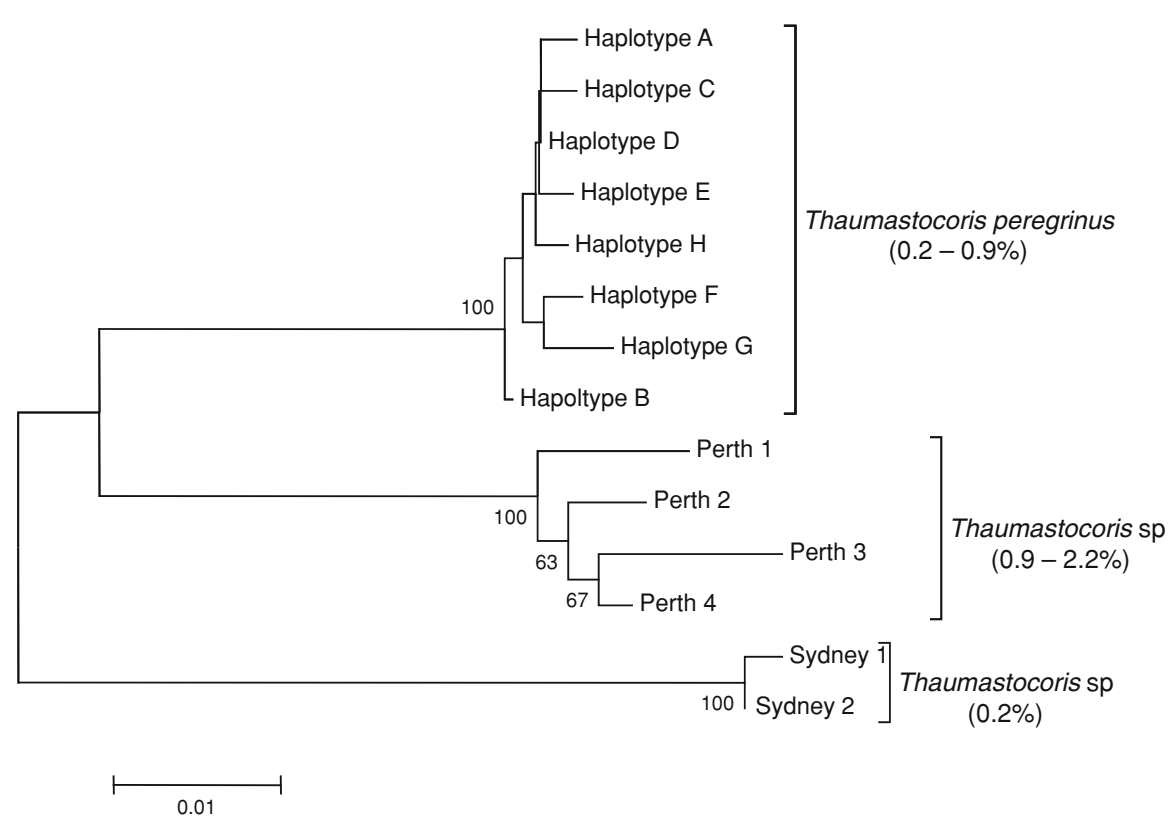

Table 2 Thaumastocoris peregrinus mtDNA COI haplotypes: the number of sequenced $T$. peregrinus individuals $(N)$ and the number of each haplotype $\left(\mathrm{H}_{\mathrm{A}-\mathrm{H}}\right)$, haplotype diversity $( \pm \mathrm{SD})$ for each of the populations sampled

\begin{tabular}{|c|c|c|c|c|c|c|c|c|c|c|}
\hline \multirow[b]{2}{*}{ Populations } & \multirow[b]{2}{*}{$N$} & \multicolumn{8}{|c|}{ Haplotypes } & \multirow[t]{2}{*}{ Haplotype diversity $(h)$} \\
\hline & & $\mathrm{H}_{\mathrm{A}}$ & $\mathrm{H}_{\mathrm{B}}$ & $\mathrm{H}_{\mathrm{C}}$ & $\mathrm{H}_{\mathrm{D}}$ & $\mathrm{H}_{\mathrm{E}}$ & $\mathrm{H}_{\mathrm{F}}$ & $\mathrm{H}_{\mathrm{G}}$ & $\mathrm{H}_{\mathrm{H}}$ & \\
\hline Sydney (2001-2002) & 35 & 12 & - & - & 11 & 1 & - & 7 & 4 & $0.7513 \pm 0.0347$ \\
\hline Sydney (2008) & 36 & 16 & & 1 & 10 & - & - & 2 & 7 & $0.7032 \pm 0.0463$ \\
\hline Brisbane (2008) & 7 & - & 1 & - & 5 & - & 1 & - & - & $0.5238 \pm 0.2086$ \\
\hline South Africa & 62 & - & - & - & 46 & - & - & 16 & - & $0.3892 \pm 0.0538$ \\
\hline South America & 32 & 32 & - & - & - & - & - & - & - & 0 \\
\hline
\end{tabular}

coastal Zululand region of northern KwaZulu-Natal (Fig. 2). This second haplotype appeared only in samples collected subsequent to March 2006 where it was present at one site. Eight months later (November 2006) it had spread along the coast to two adjacent sites where it now co-occurs together with the dominant haplotype.

\section{Discussion}

Surveys and collections done as part of this study, confirmed the establishment of $T$. peregrinus in regions of the Southern Hemisphere between 2003 and 2006. Extreme long range dispersal by air travel from urban centres in Australia, where outbreaks of this pest have occurred over the past 10 years, are suggested as being the most likely initial dispersal mechanism of $T$. peregrinus into South Africa and South America. The establishment and spread of T. peregrinus across South Africa and South America appears to have been through stratified dispersal (Lockwood et al. 2007), encompassing both long and short distance modes of dispersal (Liebhold and Tobin 2008). Long range dispersal mechanisms are principally thought to be through human mediation and wind (Pasek 1988; Smith et al. 2007), which would result in the spread and establishment of numerous isolated $T$. peregrinus populations, as was noted to occur within South Africa in 2006 (Fig. 2). Once established these isolated populations are expected to grow in size and eventually coalesce 
Fig. 4 The haplotype distribution and network of 186 Thaumastocoris peregrinus $\mathrm{COI}$ sequences. A haplotype network of the eight haplotypes. Haplotype frequencies are represented by the area of the circles. Each line corresponds to a mutational step. Black circles represent haplotypes not observed during sampling. Different patterns represent different populations

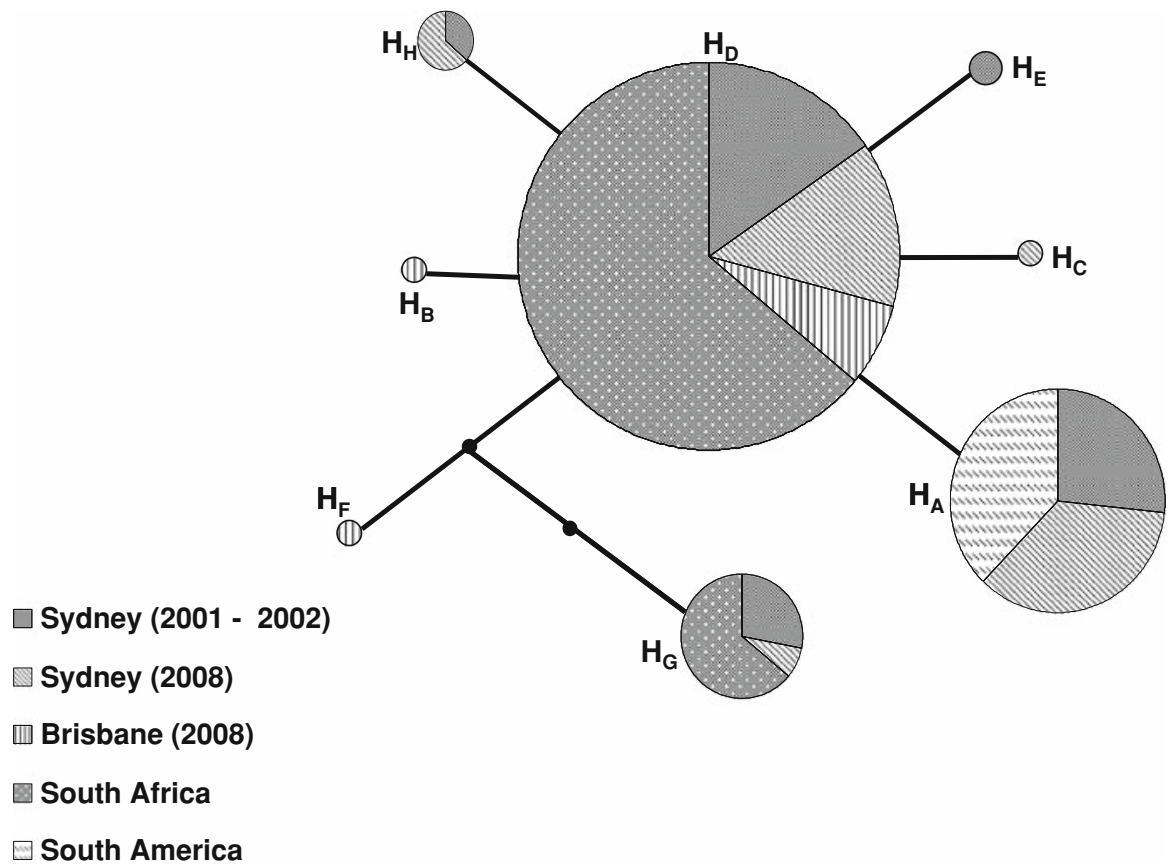

with neighbouring populations. This is in comparison to the situation if only short distance dispersal mechanisms had occurred (Liebhold and Tobin 2008; Lockwood et al. 2007).

Thaumastocoris peregrinus has a wide host range attacking at least 30 Eucalyptus species and three common commercial hybrids. In South Africa, 26 species including all commercially grown Eucalyptus are susceptible to attack (Table 1) (Jacobs and Neser 2005). In Australia, 14 Eucalyptus species are affected with E. scoparia and E. nicholii being most susceptible to infestation (Noack and Coviella 2006; A. Noack, unpublished data). In comparison, South American $T$. peregrinus infestations have been reported on seven Eucalyptus species (Carpintero and Dellapé 2006; Noack and Coviella 2006). The wide host range on Eucalyptus supports the establishment, survival and reproduction of T. peregrinus. This varied level of polyphagy is not uncommon and has been observed for other members of Thaumastocoris and the Thaumastocorinae sub family of the Thaumastocoridae (Cassis et al. 1999; Kumar 1964; Slater 1973).

Analysis of the bar-coding COI sequences revealed three phylogenetically distinct clades, which most likely represent three distinct Thaumastocoris species. The Thaumastocoris species could be distinguished based on their levels and pattern of mtDNA sequence divergence. Variation between clades were high $(6.7-8.7 \%)$ and in the range typical of species divergence, while that within the groups was low $(0.2-2.2 \%)$, as would be expected within species (Hebert et al. 2004). These samples were subsequently analysed morphologically, confirming the distinction of the three Thaumastocoris species, of which two appear to be undescribed species (A. Noack; unpublished data). One of these undescribed species was found to co-occur with T. peregrinus in Sydney, whereas the third species was found only in Perth, Western Australia. The clade identified as T. peregrinus confirmed that the Thaumastocoris in Sydney and Brisbane is the same species occurring in Argentina, Brazil, South Africa and Uruguay. This demonstrates the value of using $\mathrm{COI}$ as a bar-coding region to explore species diversity of Thaumastocoris.

Bar-coding not only revealed cryptic species diversity in Thaumastocoris, but it was also useful in determining a potential source and the pattern of invasion of $T$. peregrinus in South Africa and South America. T. peregrinus samples from 17 localities in Australia yielded eight mitochondrial COI haplotypes. The COI haplotype diversity of $T$. peregrinus was highest within the Sydney region, with similar diversities obtained for two sampling events. Over 
the past 7 years (2001-2008) the haplotype diversity in Sydney has thus remained relatively constant, indicating the absence of evolutionary forces such as drift, immigration or genetic bottlenecks that would result in temporal changes in population structure (Roderick 1996; Sakai et al. 2001). This is despite the urban environment and presence of parasitoids that might affect new introductions from other areas, or lead to bottlenecks when control programs result in populations crashing.

Of the three T. peregrinus haplotypes (B, D and F) sampled in the Brisbane region, two (haplotype B and F) were unique to that area. This is not surprising because there is a substantial geographic distance, where native populations of the pest would be expected to occur, between Brisbane and Sydney. The overlapping haplotype (D) is also one of the most frequent haplotypes in Sydney, and possibly reflects movement of the pest between these regions. Further sampling within the Brisbane region would, however, be necessary to make more meaningful comparisons between the Sydney and Brisbane populations.

Three of the haplotypes (A, D and G) of T. peregrinus in Australia were also found among the non-native $T$. peregrinus specimens from Argentina, Brazil and Uruguay (haplotype A) and South Africa (haplotype D and G). These haplotypes were also shown to be the most common during outbreaks in the Sydney region during 2001-2002, prior to their discovery in South Africa (since 2003) and Argentina (since 2005). The occurrence of only these three haplotypes (A, D and G) outside of Australia, indicates that a small number of individuals, were most likely introduced into South Africa and South America. The lower haplotype diversity present in the non native populations of $T$. peregrinus, are in agreement with a recent review indicating that $80 \%$ of genetic diversity studies have shown lower genetic diversity in invasive as opposed to native populations (Puillandre et al. 2008).

The presence of distinct haplotypes in South Africa and South America also indicates that the insect has not moved between these continents, but that they more likely represent separate introductions from Australia. These multiple introductions reflect the apparent ease with which $T$. peregrinus has been introduced into new environments, and the threat of new introductions in future. The haplotypes A and D that are most common in Sydney (from 2001 to 2002 and 2008 collections) are also those found in South Africa (D) and South America (A). This indicates that the Sydney area is the most likely origin of the other southern hemisphere introductions although an introduction from the Brisbane region to South Africa is also possible. The most common haplotypes in a source population are those that are more likely to be sampled and to eventually spread (Ficetola et al. 2008; Roderick 1996; Sakai et al. 2001) and this also appears true for $T$. peregrinus in the present study.

Two $T$. peregrinus mtDNA haplotypes were found to occur in South Africa. The dominant haplotype D was found throughout South Africa spanning all climatic regions, whereas the second haplotype $G$ was only found within the summer rainfall area of KwaZulu-Natal. This second haplotype appeared only in samples found at a single site in March 2006. After several months, it was detected further along the coast at sites where it now occurs together with the dominant haplotype D. The locality of the first report of this second South African haplotype and its subsequent spread into new areas after its initial discovery (May 2006), suggests that this haplotype represents a second independent introduction of the pest into South Africa from the Sydney population. Based on their distribution, possible ports of entry for specimens representing the two haplotypes are the O. R. Tambo International Airport in Gauteng and the harbour at Richards Bay in Northern KwaZulu-Natal.

Bar-coding revealed three separate introductions of T. peregrinus from Australia, most likely via extreme long distance dispersal in a short period of time. It is interesting to note that the introductions into South Africa and South America (2003-2005) coincide in time with the outbreaks of the pest in Sydney that have occurred regularly during the past 10 years. Large population build-ups in the Sydney region are suggested to have resulted in the separate unconnected introductions of this pest into South African and South American non-native Eucalyptus plantations. Because T. peregrinus populations remain high in Sydney, further introductions and a greater diversity is expected to appear in $T$. peregrinus populations in South Africa and South America in coming years. Results of this study have highlighted the threat of outbreaks of pests in urban centres where the large numbers of insects can increase the chances of their accidental movement to other urban centres in a 
country or elsewhere in the world. These cosmopolitan centres are often hubs linking transport systems between different countries and continents and they should be considered important sources of new introductions.

Acknowledgments Members of the Tree Protection Cooperative Programme (TPCP), the Department of Trade and Industry THRIP programme and the National Research Foundation (NRF) are thanked for financial support. We also thank Dr. Jose Garcia who made it possible for us to collect specimens in Uruguay. Prof. Jolanda Roux and Mr. Brett Hurley kindly provided photographs used in Fig. 2e, f, respectively. An anonymous reviewer and the editor are thanked for their comments, which greatly improved the quality of the manuscript.

\section{References}

Bickford D, Lohman DJ, Sodhi NS, Ng PKL, Meier R, Winker K, Ingram KK, Das I (2007) Cryptic species as a window on diversity and conservation. Trends Ecol Evol 22:148-155

Brockerhoff EG, Liebhold AM, Jactel H (2006) The ecology of forest insect invasions and advances in their management. Can J For Res 36:263-268

Brooker MIH (2000) A new classification of the genus Eucalyptus L'Hér. (Myrtaceae). Aust Syst Bot 13:79-148

Brown JK (2004) Tracing the origin of cryptic insect pests and vectors, and their natural enemies. In: Ehler LE, Sforza R, Mateille T (eds) Genetics, evolution and biological control. CABI Publishing, Wallingford, pp 113-135

Carpintero DL, Dellapé PM (2006) A new species of Thaumastocoris Kirkaldy from Argentina (Heteroptera: Thaumastocoridae: Thaumastocorinae). Zootaxa 1228:61-68

Cassis G, Schuh RT, Brailovsky H (1999) A review of Onymocoris (Heteroptera: Thaumastocoridae), with a new species, and notes on hosts and distributions of other thaumastocorid species. Acta Societatis Zoologicae Bohemicae 63:19-36

Clement M, Posada D, Crandall KA (2000) TCS: a computer program to estimate gene genealogies. Mol Ecol 9:16571660

Drake CJ, Slater JA (1957) The phylogeny and systematics of the family Thaumastocoridae (Hemiptera: Heteroptera). Ann Entomol Soc Am 50:353-370

Ficetola GF, Bonin A, Miaud C (2008) Population genetics reveals origin and number of founders in a biological invasion. Mol Ecol 17:773-782

Forestry South Africa (2006) Abstract of South African Forestry facts for the year 2004/2005. Forestry South Africa, Johannesburg, p 7

Hebert PDN, Cywinska A, Ball SL, de Waard JR (2003a) Biological identifications through DNA barcodes. Proc R Soc Lond B 270:313-321

Hebert PDN, Ratnasingham S, de Waard JR (2003b) Barcoding animal life: cytochrome $c$ oxidase subunit 1 divergences among closely related species. Proc R Soc Lond B Biol Sci 270:S96-S99
Hebert PDN, Penton EH, Burns JM, Janzens DH, Hallwachs W (2004) Ten species in one: DNA barcoding reveals cryptic species in the neotropical skipper butterfly Astraptes fulgerator. Proc Natl Acad Sci USA 101:14812-14817

Heiss E, Popov YA (2002) Reconsideration of the systematic position of Thaicorinae with notes on fossil and extant Thaumastocoridae (Hemiptera: Heteroptera). Polskie Pismo Entomologiczne 71:247-259

Hill L (1988) The identity and biology of Baclozygum Depressum Bergroth (Hemiptera: Thaumastocoridae). J Aust Entomol Soc 27:37-42

Jacobs DH, Neser S (2005) Thaumastocoris australicus Kirkaldy (Heteroptera: Thaumastocoridae): a new insect arrival in South Africa, damaging to Eucalyptus trees. S Afr J Sci 101: 233-236

Kirkaldy GW (1908) Memoir on a few heteropterous Hemiptera from Eastern Australia. Proc Linn Soc NSW 32:768-788

Kumar R (1964) Anatomy and relationships of Thaumastocoridae (Hemiptera: Cimicoidea). J Entomol Soc QLD 3:48-51

Liebhold AM, Tobin PC (2008) Population ecology of insect invasions and their management. Annu Rev Entomol 53: 387-408

Lockwood JL, Hoopes MF, Marchetti MP (2007) Invasion ecology. Blackwell Publishing, Malden, p 299

Noack AE (2002) Thaumastocoridae-an investigation. Retrieved from http://pandora.nla.gov.au/pan/32881/20030 204/www.thaumastocoridae.org/index.html on 10 January 2009

Noack AE, Coviella CE (2006) Thaumastocoris australicus Kirkaldy (Hemiptera: Thaumastocoridae): first record of this invasive pest of Eucalyptus in the Americas. Gen Appl Entomol 35:13-15

Pasek JE (1988) Influence of wind and windbreaks on local dispersal of insects. Agric Ecosyst Environ 22:539-554

Puillandre N, Dupas S, Dangles O, Zeddam JL, CapdevielleDulac C, Barbin K, Torres-Leguizamon M, Silvain JF (2008) Genetic bottleneck in invasive species: the potato tuber moth adds to the list. Biol Invasions 10:319-333

Roderick GK (1996) Geographic structure of insect populations: gene flow, phylogeography, and their uses. Annu Rev Entomol 41:325-352

Rozas J, Sánchez-Delbarrio JC, Messeguer X, Rozas R (2003) DnaSP, DNA polymorphism analyses by the coalescent and other methods. Bioinformatics 19:2496-2497

Rozen S, Skaletsky HJ (1998) Primer3. Retrieved from http://www-genome.wi.mit.edu/genome_software/other/ primer3.html. On 13 September 2006

Sakai AK, Allendorf FW, Holt JS, Lodge DM, Molofsky J, With KA, Baughman S, Cabin RJ, Cohen JE, Ellstrand NC, McCauley DE, O’Neil P, Parker IM, Thompson JN, Weller SG (2001) The population biology of invasive species. Annu Rev Ecol Syst 32:305-332

Simon C, Frati F, Beckenbach A, Crespi B, Liu H, Flook P (1994) Evolution, weighting, and phylogenetic utility of mitochondrial gene sequences and a compilation of conserved polymerase chain reaction primers. Ann Entomol Soc Am 87:651-701

Slater JA (1973) A contribution to the biology and taxonomy of Australian Thaumastocoridae with the description of a new species (Hemiptera: Heteroptera). J Aust Entomol Soc 12:151-156 
Smith RM, Baker RHA, Malumphy CP, Hockland S, Hammon RP, Ostojá-Starzewski JC, Collins DW (2007) Recent nonnative invertebrate plant pest establishments in Great Britain: origins, pathways, and trends. Agric For Entomol 9: 307-326

Tamura K, Dudley J, Nei M, Kumar S (2007) MEGA 4: molecular evolutionary genetic analysis (MEGA) software version 4.0. Mol Biol Evol 24:1596-1599
Turnbull JW (1999) Eucalypt plantations. New Forest 17:37-52 Wingfield MJ, Slippers B, Roux J, Wingfield BD (2001) Worldwide movement of exotic forest fungi, especially in the tropics and the Southern Hemisphere. Bioscience 51: 134-140

Wingfield MJ, Slippers B, Hurley BP, Coutinho TA, Wingfield BD, Roux J (2008) Eucalypt pests and diseases: growing threats to plantation productivity. South For 70:139-144 